\title{
Medial Subtalar Dislocation: Case Report and Review of the Literature
}

Mohamed Rida El Galiou*, E.Y. Houass, M.Boufettal, R.A. Bassir, M. Kharmaz, M.O. Lamrani, M.S. Berrada

Department of Orthopedics and Traumatology, University Hospital Center of Rabat, Faculty of Medicine and Pharmacy of Rabat, University Mohammed V Souissi, Rabat, 10000, Morocco

DOI: $10.36347 /$ sjams.2020.v08i12.014

| Received: 24.11.2020 | Accepted: 07.12.2020 | Published: 14.12.2020

*Corresponding author: Mohamed Rida El Galiou

\section{Abstract}

Subtalar dislocation is a very rare lesion. This is an orthopedic emergency. The authors report the case of a young sports patient who presented a stage I open internal talar dislocation of Couchoix Duparc following a sports accident during a competition. The treatment was orthopedic. After one year of follow-up, the functional result was satisfactory.

Keywords: Internal dislocation, subtalar joint, sports accident.

Copyright $(\mathcal{C}) 2020$ The Author(s): This is an open-access article distributed under the terms of the Creative Commons Attribution 4.0 International License (CC BY-NC 4.0) which permits unrestricted use, distribution, and reproduction in any medium for non-commercial use provided the original author and source are credited.

\section{INTRODUCTION}

Pure subtalar dislocation is the displacement of the calcaneo-pedis unit below the talus held in the tibiofibular mortise, without associated fracture. Pure acute medial subtalar dislocation (LST) without associated lesion is rare [1-3]. It most often follows a high-energy equine varus trauma [1], a fall from a height, a road accident or a sports accident $[2,3]$.

\section{Clinical Observation}

This is a 25-year-old patient with no particular pathological history who suffered a trauma to the right ankle following a sports accident (during a football match) with reception of a jump in inversion and equinism of the right foot. The clinical study objectified pain with total functional impotence, a deformation of the mid-tarsal region with puncture-shaped cutaneous opening, stage I by Couchoix Duparc, facing the external malleolus (fig. 1) and without vasculo-nerve damage. The initial radiological assessment revealed a pure internal subtalar dislocation without associated fractures (fig. 2). The reduction was performed urgently under general anesthesia using the boot puller maneuver. Clinical testing confirmed the stability of the subtalar joint and the control X-ray showed good joint congruence (Fig. 3). The ankle was then immobilized in a windowed cast boot for 6 weeks without support followed by functional rehabilitation. The functional result was excellent with a follow-up of 1 year and the return to sport was authorized at 3 months.

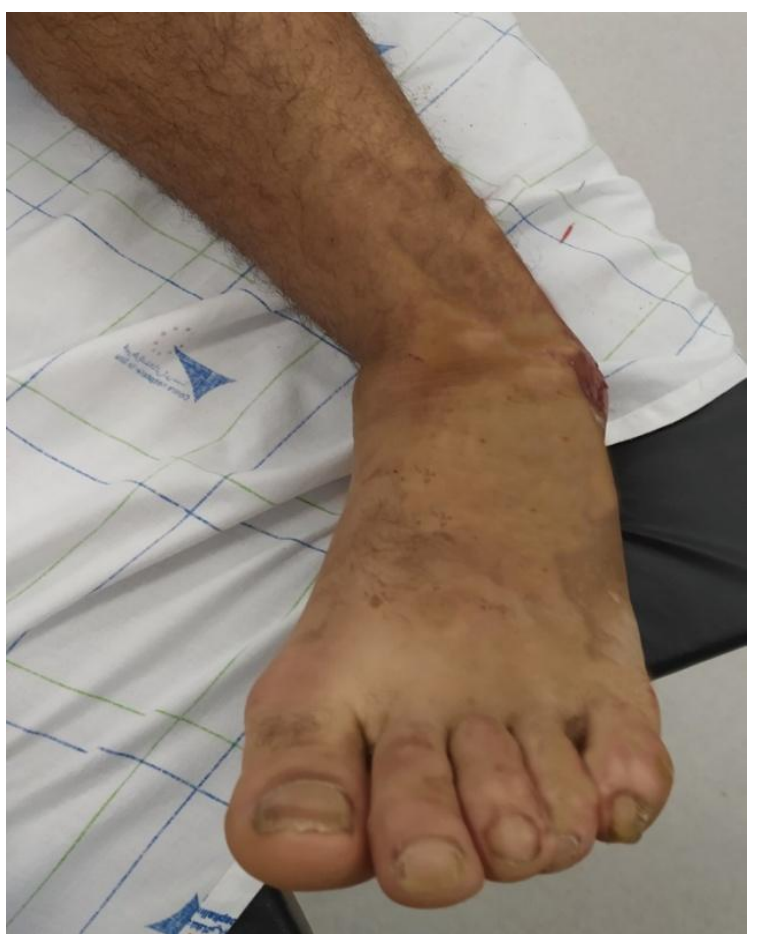

Fig-1: Picture showing the deformity of the mid-tarsal region 

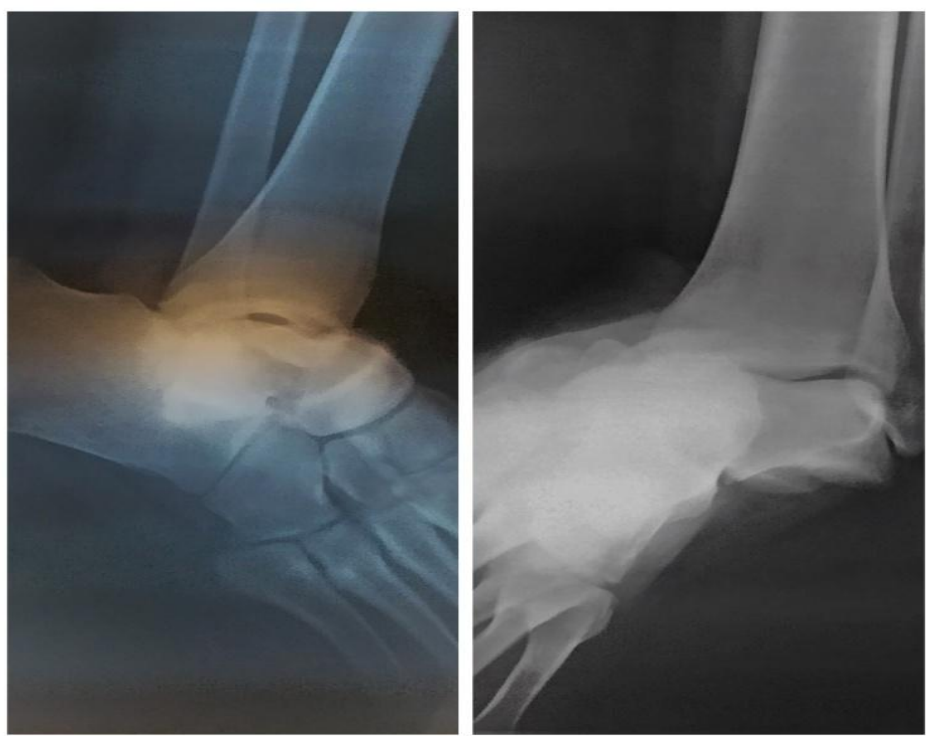

Fig-2: X-ray of the ankle, face and profile, showing a pure internal subtalar dislocation without associated fractures
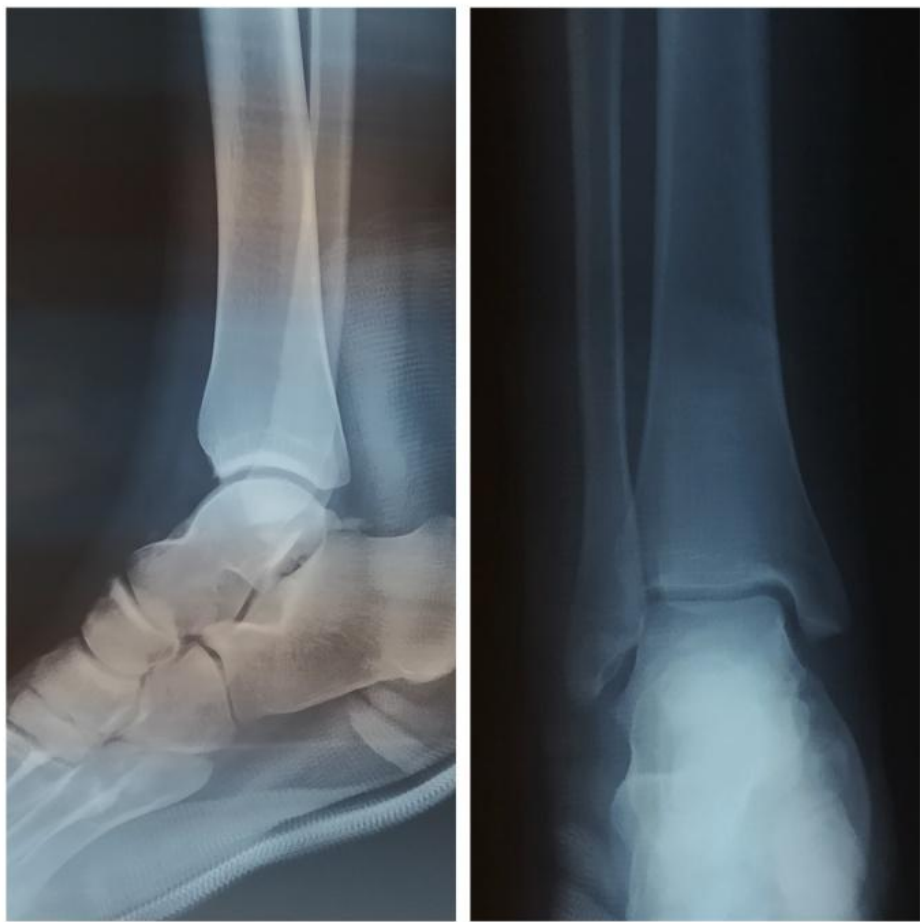

Fig-3: Check x-ray of the ankle, face and profile, showing reduction in dislocation

\section{DiSCUSSION}

Acute subtalar dislocation accounts for 1 to $2 \%$ of all joint dislocations and approximately $15 \%$ of perital lesions [3-5]. They represent about $1 \%$ of all traumatic foot injuries [6]. The sex ratio is three to four times greater in men $[2,3]$. The medial shape is predominant because the subtalar joint exhibits a large inversion displacement favoring its instability [4]. The mechanism of the medial subtalar dislocation is a forced inversion with the foot blocked on the ground causing a ligament rupture in a precise chronological order: it is first the dorsal talonavicular ligament which is damaged, then the two bundles of the ligament. Interosseous or hedge ligament and finally the fibula- calcaneal ligament [7]. Medial subtalar dislocation is usually the result of high-energy trauma (fall from a high place, traffic accident, sports accident) [1-4]. In some athletes, this forced inversion mechanism on an already inverted foot is called a "basketball foot" [1]. More rarely, cases of LST have been described for accidents with low kinetics [3]. The clinical deformity is evident, frequently associated with various lesions such as skin opening, fractures (talus: head, neck, posterior talus process; internal or external malleolus; base of the fifth metatarsal) and neurovascular involvement. Facial, lateral and three-quarter length $\mathrm{x}$ rays of the ankle and foot confirm the diagnosis and assess the integrity of the tibiotalar joint, the presence 
of malleolar fractures and associated tarsal bones, which may modify the definitive therapeutic approach [6].

The treatment consists of emergency reduction under general anesthesia. The commonly used technique requires analgesia or anesthesia in order to achieve optimum muscle relaxation and thus reduce damage to joint surfaces during manipulation. The ipsilateral knee is flexed to relax the gastrocnemius muscles. Firm longitudinal traction of the foot is applied with counter traction on the leg initially combined with increased strain. This is followed by a reverse deformity (eversion for medial dislocation and inversion for lateral dislocation) [8]. Irreducibility may be due to interpositions of the tendons of the peroneal muscles, the frondiform ligament, the extensor digitorumbrevis muscle or a bone fragment for medial dislocations [9]. The reduction is usually stable and does not justify, for pure dislocation, no principle osteosynthesis [10].

A post-reduced ankle CT scan is recommended to identify occult fractures or other osteochondral lesions that may have gone unnoticed [2-4]. These occult lesions are present in 39 to $88 \%$ of cases [6]. In a second step, the ligament and soft tissue assessment can be performed with magnetic resonance imaging, the value of which is zero in emergency [8]. The prognosis for these dislocations is relatively good [7].

Stiffness is the most common complication, osteoarthritis, avascular necrosis of the talus and instability of the subtalar joint $[4,6,9]$. The functional results of these dislocations mainly refer to the American Orthopedic Foot and Ankle Society (AOFAS) specific hindfoot score of 0 to 100 .

\section{Conclusion}

Pure internal subtalar dislocation is a rare trauma condition. The orthopedic treatment, in emergency, consists of a reduction followed by a cast contention for 6 weeks, except in the case of irreducibility by ligament incarceration where a surgical reduction is necessary.

\section{REFERENCE}

1. Gantsos A, Giotis D, Giannoulis DK, Vasiliadis HS, Georgakopoulos N, Mitsionis GI. Conservative treatment of closed subtalar dislocation: a case report and 2 years follow-up. The Foot. 2013 Jun 1;23(2-3):107-10.

2. Rida-Allah B, Hicham A, Mahfoud M, Elbardouni A, Berrada M, Elyaacoubi M. Rare case of pure medial subtalar dislocation: Conservative treatment and 32 months follow-up. Journal of Emergencies, Trauma and Shock. 2015 Jul 1;8(3):174.

3. Pesce D, Wethern J, Patel P. Rare case of medial subtalar dislocation from a low-velocity mechanism. The Journal of emergency medicine. 2011 Dec 1;41(6):e121-4.

4. DeLee JC, Curtis R. Subtalar dislocation of the foot. The Journal of bone and joint surgery. American volume. 1982 Mar;64(3):433-7.

5. Valero P, Coulomb R. La luxation sous-talienne médiale isolée traumatique. Annales françaises de médecine d'urgence. 2018 Nov 1;8(6):390-2.

6. Prada-Cañizares A, Auñón-Martín I, y Rico JV, Pretell-Mazzini J. Subtalar dislocation: management and prognosis for an uncommon orthopaedic condition. International orthopaedics. 2016 May 1;40(5):999-1007.

7. Amar MF, Chbani B, Loudyi D, Marzouki A, Boutayeb F. Luxation sous-talienne pure chez un footballeur (à propos d'un cas). Journal de traumatologie du sport. 2009 Dec 1;26(4):250-2.

8. Valero P, Coulomb R. La luxation sous-talienne médiale isolée traumatique. Annales françaises de médecine d'urgence. 2018 Nov 1;8(6):390-2.

9. Nkaoui M, Boufettal M, Sasbou Y, Kharmaz M, El Ouadaghiri M, Lamrani MO, El Bardouni A, Mahfoud M, Berrada MS. Luxation sous-talienne interne pure: à propos d'un cas. Pan African Medical Journal. 2017;27(1).

10. Jarde O, Trinquier-Lautard JL, Mertl P, Tran F, Vives P. Les luxations sous-astragaliennes, à propos de 35 cas. RevChirOrthop. 1996; 82(1):428. 